\title{
Beyond deindustrialization: changes in the pattern of industry organization and accumulation in a scenario of the 'Brazilian Disease' *
}

\author{
Antônio Carlos Diegues ** \\ Caroline Gut Rossi ${ }^{* * *}$
}

\begin{abstract}
This paper aims to analyze the changes in the pattern of organization and accumulation of the Brazilian industry in the 2000s. In accordance with the thesis presented here, since the defensive reaction to the crisis of developmentalism and the transformations derived from the exhaustion of the Fordist techno-economic paradigm in the second half of the twentieth century, the emergence of a new pattern of organization and accumulation of the local industry, termed the Brazilian Disease, was consolidated in the first decade of the $21^{\text {st }}$ century. This pattern is characterized by structural reconfigurations toward regressive specialization and deindustrialization alongside the emergence of strategies that ensured the accumulation of capital invested in the industrial sphere. This accumulation, in turn, was associated with the emergence of strategies increasingly disconnected from a strictly productive performance.
\end{abstract}

Keywords: Industry; Deindustrialization; Development; Brazilian Disease.

\section{Resumo}

Além da desindustrialização: transformações no padrão de organização e acumulação da indústria em um cenário de 'Doença Brasileira'

O objetivo deste artigo é analisar as transformações no padrão de organização e acumulação da indústria brasileira na primeira década de 2000. Segundo a interpretação defendida neste trabalho, a partir da reação defensiva à crise do desenvolvimentismo e às transformações derivadas do esgotamento do paradigma tecnoeconômico vigente na segunda metade do século XX, observou-se na primeira década de 2000 a emergência de um novo padrão de organização e acumulação da indústria local, denominado de Doença Brasileira. Essa seria caracterizada por um cenário em que se verificam reconfigurações estruturais em direção à especialização regressiva e à desindustrialização em paralelo ao surgimento de estratégias que garantiram a acumulação do capital investido na esfera industrial. Tal acumulação, por sua vez, estaria associada à emergência de estratégias crescentemente desvinculadas do desempenho estritamente produtivo.

Palavras-chave: Indústria; Desindustrialização; Desenvolvimento; Doença Brasileira.

JEL L060, O54, O14, L16.

\footnotetext{
${ }^{*}$ Article received on October 6, 2016 and approved on April 1, 2019.

${ }^{* *}$ Coordinator at the Center for Industrial Economics and Technology - Economics Department, State University of Campinas (IE/Unicamp), Campinas, SP, Brazil. E-mail: diegues@ unicamp.br.

${ }^{* * *}$ MSc in Economics, Federal University of São Carlos campus Sorocaba, Sorocaba, SP, Brazil. E-mail: carolgut@gmail.com.
} 


\section{Introduction ${ }^{1}$}

The Brazilian industry has undergone changes in recent decades that have led to an intense debate about the existence of a possible ongoing process of deindustrialization in the country. Concern surrounding this phenomenon gained momentum in the 1990s, when, after economic and financial opening, the decline in industry participation in GDP was aggravated. In recent decades several economists of different theoretical stances have tried to analyze the performance of the Brazilian industry and its relationship with national economic dynamics. Despite divergences, especially with regard to its central role in economic development, there seems to be a certain consensus in relation to two points: (i) the correlation between the low dynamism of investment in manufacturing and the aggregate investment, as well as their quantitative effects on the low economic growth; and (ii) the relationship of mutual determination between this low dynamism of manufacturing investment and the fall in competitiveness of the local industry ${ }^{2}$.

Thus, in order to contribute to the debate, the objective of this paper is to analyze the changes in the pattern of organization and accumulation of the Brazilian industry in the first decade of the 21 st century. When analyzing such transformations, we propose that, from the defensive reaction to the crisis of developmentalism and the transition of the Chandlerian techno-economical paradigm into one based on microelectronics and network firms, it is possible to observe the emergence of a new pattern of organization and accumulation of the local industry in the first decade of the $21^{\text {st }}$ century, a pattern here termed the Brazilian Disease.

The latter is characterized, during the period proposed, by a scenario in which a process of regressive specialization of the productive structure, with strong indications of deindustrialization, coexists alongside the maintenance and even increase in the accumulation of capital invested in the local industry. This accumulation, in turn, is associated with the emergence of strategies increasingly disconnected from a strictly productive performance ${ }^{3}$.

Thus, this paper argues that the low productive dynamism of the local industry, even in a scenario of economic growth up to 2010, was, in fact, the symptom of a successful pattern of organization and accumulation, active in the first decade of the $21^{\text {st }}$ century. That is, we understand that the Brazilian industry has been able to adapt and reconfigure its productive activities, gradually reducing the local content added to its production. This reduction, in turn, was accompanied by increased imports of final products, parts, pieces and components from

(1) Some excerpts of this work, materialized in a preliminary and partial version, were disclosed in a non-academic communication outlet.

(2) This relationship, however, has different meanings of causality for development-oriented and liberal economists.

(3) The phenomenon that this article understands as characteristic of a Brazilian Disease is distinguished from that presented by David Kupfer in an opinion piece published on April 04, 2007 in the financial newspaper Valor Econômico. According to the author, "it is the known vicious circle in which the low dynamism of the internal market, the increasing pressure of imported products and the reduction of profitability of exports undermine the incentives for company investments, without which there is a decrease in productivity reactions, without which the ability to live with the highly valued exchange rate declines. This, perhaps, is the essence of the "Brazilian disease"' (free translation). 
the import-oriented integration into global production chains and the increase in industrial sector profits.

In order to develop these arguments, this article is divided into four sections, in addition to this introduction. The second section presents the relationship between the industry and economic development. In the third, the different interpretations of the deindustrialization process in Brazil are analyzed. We then seek to briefly systematize such contributions departing from a taxonomy that aggregates the different takes on this process into four strands: neodevelopmentalist, liberal, social-developmentalist and the business elite from the state of São Paulo, represented by FIESP (the Federation of Industries of the State of São Paulo). The fourth section, titled "Deindustrialization and the Brazilian Disease", suggests a new interpretation of the transformations in the pattern of organization and accumulation of the Brazilian industry in the 2000s. The conclusions are presented in the final section.

\section{Industry and development}

Economic development is closely related to changes in the productive structure. According to Rodrik (2007), "the hallmark of development is structural change - the process of pulling the economy's resources from traditional low-productivity activities to modern highproductivity activities." He continues, "this is far from an automatic process, and requires more than well-functioning markets. It is the responsibility of industrial policy to stimulate investments and entrepreneurship in new activities (...)" (Rodrik, 2007, p. 7).

Similarly, when analyzing the relationship between transformations in the productive structure and productivity growth, Hirschman (1958) highlights the central role of the industry. According to the author, this centrality is related to the capacity of industrial activities to work as important vectors in spreading dynamism in the economy, through the high degree of backward and forward linkages.

Also with regard to the quantitative and qualitative impacts of the industry in other economic activities, Kaldor (1967) states that the unique characteristics of the industrial sector make it a source of dynamism and driver of long-term growth. By observing this perception derived from Kaldor's statistical analyses in the 1960s and 1970s, Thirwall (1983) suggests the systematization of his contributions in what is conventionally called Kaldor's growth laws, which can be enunciated as follows: ${ }^{4}$ (i) the growth of the industrial sector is the source of the growth of the economy as a whole, particularly given its ability to increase the pace of technological innovation; (ii) the relationship between the growth of the industrial sector and the growth of industry productivity should be understood as a causal one, in which the rise in demand for industrial products leads to an increase in production, which, in turn, increases economies of scale, increases the degree of division of labor and introduces new machines and

(4) A discussion on the origins of Kaldor's Laws and their different interpretations go beyond the objectives of this work. Those who are interested can consult Feijó and Carvalho (2007), for example, who discuss Kaldor's theoretical developments, analyzing their propositions in light of the Brazilian experience after the commercial opening. 
processes; (iii) the rise of demand-driven industrial production promotes a labor transfer from other sectors of the economy to the industry, where productivity is higher, making the national product grow more than with increased employment in other sectors, where productivity is lower; (iv) the main source of economic growth is external demand for industrial products, and this growth is basically due to the pursuit of new markets and an agility in the ability to meet external demand, which leads, via the Keynesian multiplier and backward linkages, to the growth of internal consumption and investment. Therefore, Kaldor, despite using the economic performance of central economies as an object of his analysis, saw industrial growth as the strength and the vehicle of economic growth in general.

Kaldor's approach largely focuses on the fact that the industry exhibits increasing returns to scale, which influences the growth in productivity of the economy as a whole. Therefore, the industry would work as a propellant of economic development, as it would boost itself and create incentives that would lead to the mechanization, in varying degrees, of other activities (Thirlwall, 1983). Moreover, given that the income elasticity of external demand for manufactured goods is greater than the income elasticity of external demand for commodities and primary products, industrialization is necessary to alleviate the restriction to the balance of payments (McCombie; Thirlwall, 1994; Thirlwall, 2005).

Similarly, and from a perspective that analyzes development processes in a comparative perspective, authors such as Rowthorn and Ramaswany (1999) and Kuznets (1966) qualify economic development as a three-phase phenomenon. The first phase, according to this view, is marked by the major participation of the primary sector in the GDP, which exhibits a progressive increase in productivity. Over time and owing to the increased productivity, the surplus labor from the agricultural sector moves into urban areas, finding employment in the industry and the services sector, though to a lesser extent. In this context, the second phase of development is characterized by a rise in productivity in the industrial sector, which, as with the primary sector in the previous phase, increases its productivity and releases surplus labor into a growing sector, the services sector. The third and final phase of economic development is marked by an increase in the participation of the tertiary sector in GDP. With the increase in productivity in the processing industry and in view of its growing returns to scale, a portion of the workforce shifts to the service sector, which expands as a reflection of a maturation of the country's development stage (Rowthorn; Ramaswany, 1999).

This last phase of development, in which the industry loses its relative share of GDP (without necessarily reducing the gross value of production and value added in absolute terms) is called post-industrialization, or positive deindustrialization (Palma, 2005). According to this vision and as a consequence of a successful industrialization process, the industry loses relative participation in a positive way, or as expected, without the decrease in its growth rate damaging other sectors and overall economic development.

However, according to authors related to the structuralist tradition of the Economic Commission for Latin America and the Caribbean (ECLAC), such as Raul Prebisch (1949), 
the deindustrialization process cannot be considered natural, since industry is a key sector for economic development and continues to be so even after the consolidation of the industrialization process. According to Prebish, industrialization is conditional on the historical development processes of a given country. In the case of Latin America and its lateindustrialization countries, trade relations with industrialized nations have compromised the installation of a robust industrial capacity capable of spreading dynamism to the rest of the economy.

According to ECLAC researchers Benavente et al. (2010), neoclassical authors have underestimated the importance of the industrial policies adopted by Latin American countries in the post-war period and the achievements attained during the process of import substitution industrialization (ISI). Cimoli et al. (2005) hold that what determines the performance of a given economy in relation to the international economy is its capacity to promote structural changes in accordance with the dominant technologies of its time. Thus, according to ECLAC, each country can follow a unique trajectory of growth and development, which is largely determined by its ability to absorb international technological evolutions and historical factors. Thus, decreased industrial sector participation at the expense of increased participation of services in an economy's production and employment would not occur naturally. In this sense, deindustrialization could represent, following Kaldorian and ECLAC interpretations, an obstacle to economic development.

\section{A brief take on interpretations of the changes in the Brazilian productive structure in the 2000s}

This section presents a summary of different readings on the transformation process of the Brazilian productive structure. The main aim is to identify patterns of correlated interpretations and systematize their contributions so as to group them in a taxonomy that can represent the main stylized arguments on the transformation of the Brazilian productive structure in the first decade of the $21^{\text {st }}$ century. It is worth noting, however, that the objective of this taxonomy is not as a contribution of this paper to the debate. The goal is that such a taxonomy, by arraying and organizing the arguments found in the literature, may present the interpretation with which the thesis defended in this article will debate. That is, the construction of such a taxonomy will support the present study.

By analyzing some shortcomings of these different outlooks in order to understand the dynamics of organization and accumulation of the Brazilian industry in the 2000s (hereafter representing the first decade of the present century), we sought to construct an alternative interpretation (labeled the Brazilian Disease), which represents the main contribution of this work.

In general, as will be exposed in detail in the next section, the interpretation of the Brazilian Disease questions: (i) the assertion that the reduction in the accumulation capacity of the Brazilian industry in the 2000s explains an important part of the fall in dynamism and the resulting loss of its relative importance in the Brazilian economy, as suggested by the neo- 
developmentalist analytical approach; (ii) the idea that the increase in domestic production costs in the aforementioned decade (mainly those related to the growth of wages above productivity) was responsible for the erosion of local competitiveness and the ensuing intensification of deindustrialization, as suggested by the São Paulo business elite; and (iii) the liberal thesis by which the alleged non-integration to global production networks would be one of the main causes of the deterioration of the growth capacity and increase in productivity of the domestic industry. Finally, anticipating analyses that will be presented in the next section, the Brazilian Disease interpretation suggests that, although the appreciation of the local currency is central to understanding the lower productive dynamism of the 2000s, as the socialdevelopmentalists argue, a valued exchange rate played an important role in increasing the capacity of industry accumulation in the period.

With an understanding of how the systematization of outlooks on Brazilian productive structure dynamics and the phenomenon of deindustrialization in the 2000s through a taxonomy contributes to the construction of the thesis supported here, we move on to present the main arguments of these interpretations.

In order to group them according to a taxonomy, we consider, like Bielschowsky $(1988)^{5}$, that institutional and political elements, in addition to differences with regard to theoretical foundations, condition the distinct interpretations present in the debate about the phenomenon. Thus, to construct such segmentation, this article seeks to subdivide the interpretations according to criteria such as theoretical foundations, classification of the importance of industry for development, determinants of the processes of transformation of the productive structure and institutional infrastructure, as well as prescriptive guidelines of industrial policy suitable for industrial development. Additionally, similarly to Bielschowsky (1988), the analytical approaches were segmented according to institutional and political links. Thus, the taxonomy proposed in this paper synthesizes the debate on Brazilian deindustrialization into four approaches: (a) social-developmentalist, (b) neodevelopmentalist, (c) liberal, and (d) the São Paulo business elite (represented by FIESP) ${ }^{6}$.

The social-developmentalist approach characterizes the industry as the main vector of economic growth and structural transformations. Advocates of this approach share the idea that the economic development process is directly linked to industrialization, which, in turn, is historically fostered by public policies in peripheral economies (Sarti; Hiratuka, 2011) ${ }^{7}$.

(5) When analyzing the Brazilian economic thinking in the ideological cycle of developmentalism, Bielschowsky (1988) proposes segmentation into five stances: (1) neoliberal, (2) developmentalism of the private sector, (3) developmentalism of the non-nationalist public sector, (4) nationalist public developmentalism and (5) socialist.

(6) The classification in these four groups is somewhat subjective. However, we sought to group authors and institutions according to the proximity of the ideas expressed in their published works and the perception of their peers on the positioning of these authors in the debate.

(7) Despite the fact that some authors do not expressly call themselves social-developmentalists, their work was aggregated in this group due to the similarity between their interpretations and the fact that they were developed in institutions perceived by their academic peers as linked to the approach that has been conventionally termed social-developmentalism. This same restriction justifies the classification of authors in the other groups (neo-developmentalists, liberals and business elite). 
According to Cano (2012), Brazil faces an early and harmful deindustrialization, as shown by the decline in the participation of the manufacturing industry in GDP. The main causes of deindustrialization, according to the author, are the exchange policy implemented after the Plano Real, the commercial opening that started in the 1990s (and which complemented the harmful effect of the appreciated exchange rate), high interest rates and low dynamism of the productive investment (conversely to the vigor presented by investments in financial services and financial assets in portfolios, private securities and public debt).

Additionally, an important share of the global manufacturing foreign direct investment during the last decade has shifted to China in search of devalued exchange rates and low costs, which has also jeopardized the development of the national industry. One of the consequences of this scenario, according to Cano (2012), is the loss of competitiveness of Brazilian exports along with increased imports of manufactured products (mainly industrial inputs).

Cano (2012) concludes that, in a period of international crisis, the guidelines of public policies, rather than structuring liberalizing measures, should foster the strengthening of the State's capacity to guide and lead economic growth through investments and public purchasing power.

Complementarily, Hiratuka and Sarti (2015) seek to analyze the changes in the Brazilian productive structure beyond the limits that surround the debate on deindustrialization. Although they emphasize the contributions of this debate to restore the perception that industry is central to economic development, the authors point out its limitations. The principal limitation is the negligence on the part of the literature and specialists regarding the impact of transformations in the global productive system in terms of development of the national productive capacity. Among these transformations, we highlight the reconfiguration of global production chains as a result of productive activities being displaced to Asia - mainly China , the intensification of international competitive pressures and the reinforcement of the competitive positions of global oligopolies resulting from asymmetries associated with the domain of intangible assets, such as brands, marketing channels and technological capacitation.

As this scenario, according to Hiratuka and Sarti (2015), has been little explored by the three groups of authors who debated deindustrialization (classified as belonging to the mainstream, to the Kaldorian vision of growth and productive specialization, and to the convergence of a Kaldorian vision with structuralist and neo-Schumpeterian elements), it is necessary to deepen the understanding of the "fundamental and necessary elements to discuss a broader development strategy surrounding the Brazilian productive structure" (Hiratuka; Sarti, 2015, p. 17, free translation).

Given the challenges outlined in the preceding paragraph regarding "industrial Chinalization" (Sarti; Hiratuka, 2017) and the prospects of developing a set of potentially disruptive technological innovations materialized in what has been conventionally called Industry 4.0, 
factors identified as solutions, such as increasing domestic savings, conditioning the rise of wages to the expansion of productivity and achieving greater commercial openness (according to the mainstream perspective) do not seem to live up to expectations. Similarly, a change in exchange rate so that it is compatible with industrial equilibrium, as pointed out by the second approach (Kaldorians), may be a necessary, but insufficient, condition to face the challenge above. Finally, increasing the innovative activity and raising the participation of more technology-intensive sectors in the industrial structure, as highlighted by the third vision (structuralists and neo-Schumpterians), is fundamental. The main issue, however, is how to achieve this goal, given the changes that have been occurring in the global productive structure (Hiratuka; Sarti, 2015, p. 17, free translation).

To this end, it is necessary to rethink the potential and existing national productive capacities as well as the adequacy of industrial, scientific and technological policies to foster the creation of competitive asymmetries in a scenario where international competition and profound transformations in the patterns of organization of production and accumulation coexist.

It is also worth remembering that, alongside such normative guidelines associated with the need to build a solid development strategy based on national productive and technological autonomy, concerns about the deleterious role of distortions in macroeconomic prices constitute one of the important foundations from which social-developmentalist interpretations stem. The dysfunctionality of the characteristic regime of an appreciated exchange rate and high interest rates of a pattern of productivist accumulation was already observed in the seminal analyses on the effects of the opening and financial liberalization of the Brazilian economy in the 1990s presented by Coutinho (1997) and Belluzzo and Almeida (2002), among others.

In turn, the most prominent thesis surrounding the debate on deindustrialization defined by neo-developmentalist authors is that which bases the observation of such a phenomenon on the persistent exchange rate appreciation of the real, the Brazilian currency, associated with favorable conditions for the commercialization of commodities (increased international demand and prices) and the comparative advantages that Brazil already exhibits in these activities. According to this thesis, considering a lack of industrial policies that neutralize the effects of a possible Dutch disease, specialization in the domestic productive structure in less complex industrial links is observed. Thus, the commodity sector promotes high commercial surplus thanks to its high competitiveness, which harms other less competitive sectors that depend on the strengthening of a less valued exchange rate.

Stemming from this theoretical framework and analyzing the determinants of the Brazilian productive performance in the first decade of the $21^{\text {st }}$ century, Bresser-Pereira and Marconi (2010) categorically affirmed that the country had been undergoing deindustrialization as a result of the overvalued national currency. In 2005, Bresser-Pereira showed that the increase in exports, despite the continuous appreciation of the real, indicated that the country was facing the Dutch disease (Bresser-Pereira, 2005). According to the author, the Dutch disease is a phenomenon that stems from the existence of abundant natural resources 
that generate comparative advantages for the country that commercializes them. This abundance, in turn, could drive the country to specialize in producing this kind of good rather than industrializing, or interrupting its industrialization process, which would compromise economic development.

The rationale behind neo-developmentalism when analyzing the industry's contextualized performance in the 2000s is that there was a reduction in the accumulation capacity due to the Dutch disease and the maintenance of macroeconomic prices that are incompatible with increased industrial growth. The reduction of this accumulation capacity would bring with it a slowdown in productive investments, the ensuing stagnation of productivity and decreased competitiveness of the local productive capacity in the face of imports. Complementary to the impacts of the overvaluation of the local currency on the competitiveness of the Brazilian manufacturing industry, the neo-developmentalist perspective developed a thesis that seeks to justify this tendency from a profit-squeeze movement. The theory gives that, in addition to the negative impacts of an exchange rate that is shifted from the level required for industrial equilibrium, the persistent growth of the real wage above productivity during the 2000 s compromised the competitiveness and investment capacity of the local industry.

According to Bresser-Pereira and Marconi (2010), the structural solution to the problem of deindustrialization is the reorganization of relative prices in order to potentialize the accumulation of capital in the industrial sphere. On the one hand, wage growth would need to be lower than productivity growth. On the other hand, the creation of the required mechanisms to maintain industrial equilibrium exchange rate would be necessary. According to the authors, one must "(1) impose taxes on the export of goods that give rise to the Dutch disease; (2) use ensuing tax resources to reset the public deficit; (3) lower the real interest rate to the international level; and (4) establish barriers to entry of unwanted capital" (BresserPereira, 2010, free translation). The result of this set of measures would cause the income of primary goods exporters to be maintained, since the tax would be outweighed by the depreciation of the exchange rate and, gradually, the industry would resume growth. It is worth remembering that, although the deleterious impacts of an overvalued exchange rate are stressed by the social-developmentalist interpretation, the perception of these impacts on the growth models suggested by the different approaches is fundamentally distinct. This is because, while the neo-developmentalists flirt, to some extent, with prescriptive guidelines towards an exportled growth strategy, social-developmentalist normative guidelines focus on the construction of a wage-led growth model.

Despite the logical coherence of the line of argumentation advocated by neodevelopmentalists, as will be detailed in the next section, the thesis of the Brazilian Disease featured in this work questions the idea that there was a reduction in the accumulation capacity of the Brazilian industry in the first decade of the $21^{\text {st }}$ century. On the contrary, we seek to show empirically that this accumulation capacity intensified, even though it was increasingly disconnected from strictly productive activities performed domestically. 
In turn, the authors that take a liberal stance argue that the Brazilian industry was not stricken by the phenomenon of deindustrialization, since there is an international downward trend in the impact of the industry in countries' GDPs. Therefore, they believe that the transformations suffered by the manufacturing industry in Brazil do not constitute a process of deindustrialization, as a global trend was merely followed.

Bonelli and Pessoa (2010) argue that the industry is the most susceptible sector to short-term oscillations, influenced by external crises or domestic economic instabilities. In this context, the reduced participation of the Brazilian industry has always been associated with moments of crisis, since, according to the authors, "the Brazilian industry produces goods that are elastic in relation to income. Thus, in phases of prosperity, the industry tends to have a greater impact on the economy. The opposite occurs during stagnation and/or recession" (free translation).

Similarly, in several book chapters organized by Bacha and Bolle (2013), there is a certain convergence about normative guidelines which are necessary to restore the growth and competitiveness of the Brazilian industry. Among these, we highlight the formulation of a strategy for the local industry to participate in global production chains, the reform of the public sector - which, in this perspective, is inefficient in infrastructure investment -, the need to increase innovation in the industry, investments in education, and the change of the national tax system in order to reduce the high taxes paid by national companies.

Despite the importance of investments in infrastructure as catalysts of local systemic competitiveness, the following section questions the idea that the Brazilian industry presents a low level of integration into global productive networks. For this reason, it does not benefit from an alleged transmission of productivity gains by importing inputs with high technological content. Conversely, we defend the argument that this integration was deepened in the first decade of the 21 st century. That is, the domestic industry increasingly opted to intensify its import-oriented integration into the networks, shifting local productive activities externally. Given the appreciation of the local currency, this contributed to the increase in its accumulation capacity in the said period.

Lastly, with a major influence in the debate on deindustrialization, we introduce the approach of the business elite from the state of São Paulo; FIESP is the main representative of this group.

The business elite attempt to analyze the industrial performance of Brazil in the first decades of the 21 st century from a perspective which is qualitatively different from the stances described previously. In other words, given the characteristics of institutions of this nature, a less extensive analytical framework, in relation to the other approaches, is expected. The emphasis of the analyses shifts from understanding the relationship between the productive structure and development in a broader sense to analyzing (i) the binomial rate of returnincentive to investment and (ii) the competitiveness of the local productive capacity. 
As Brazilian industry dynamics in the period are mainly understood by analyzing indicators associated with return on investment, issues which are central to the social and neodevelopmentalist approaches, such as sectoral configuration, chaining capacity, transmission of productivity gains and productive diversification, are found in a lower analytical plan. It is in this sense that the analyses of the São Paulo business elite regarding an alleged deindustrialization movement in the decade mainly seek to understand how low local competitiveness affects the dynamics of industrial accumulation.

However, in public documents and statements from these representatives, the understanding of the determinants of local competitiveness is presented almost fundamentally from the cost dimension. From a generalist perspective, the idea is that the process of deindustrialization underway in the first decade of the 21 st century was derived from low local competitiveness due to the deterioration of countless factors that compose the so-called "Brazil cost". Among the elements responsible for this movement, we can cite alleged competition deemed "unfair" by FIESP - with imported products and the appreciation of the local currency, which would prevent the local industry from attending the domestic market, and thus from expanding (FIESP, 2011).

Structurally, the positions of the São Paulo business elite suggest that high tax incidence, high interest rate and adversities of the business environment are largely accountable for the low development of the local industry. Additionally, factors such as high energy costs, rigidity of labor laws and low quality of the workforce are also cited.

According to FIESP, both these gaps and the process of deindustrialization would be bypassed if a competitiveness agenda facing such bottlenecks were implemented. That is, once the conditions for increased attractiveness of industrial investment (via an increased rate of return) were established, one of the main triggering factors of deindustrialization would be interrupted (FIESP, 2013).

\section{From deindustrialization to the Brazilian disease}

The restrained resumption of investment in the Brazilian economy and the persistent trade deficit in technologically dynamic areas in recent years have highlighted the need to restore competitiveness in the local industry in order to create the foundations of a new growth cycle. However, despite the perception that the industry is central to the recovery of national growth and although there is consensus about its low competitiveness, the transformations in its organization and accumulation that took place in the 2000s substantially reduced its capacity as the growth catalyst associated with diversification and structural transformations based on the increase and dissemination of intersectoral productivity, as suggested by Kaldor (1966; 1967) and Hirschman (1958). In other words, the pattern of organization and accumulation of the local industry has gradually moved away from the virtuous binomial retention of profits and reinvestment in related activities in search of diversification that characterized Brazilian 
productive development throughout the process that was conventionally labeled developmentalist ${ }^{8}$.

The origins of this pattern of organization and accumulation of the Brazilian industry in the first decade of the 21 st century structurally date back to major transformations engendered from the last quarter of the 20th century onward. Regarding the firm's dimension, the firm-network paradigm was established, which enabled the global fragmentation of the production process, associated with the displacement of a significant portion of it to Asia and the ensuing upsurge of global competition in manufacturing activities. Alongside this phenomenon, as highlighted by Crotty (2002), the material foundations of management models based on the logic of maximization of stock price were created. These models, by demanding liquidity and short-term performance of industrial companies, were based on strategies that required their increasing concentration in strictly non-manufacturing activities, among which are those of the financial sphere. For such, the author shows that what was needed was:

a shift in the beliefs and behavior of financial agents, from an implicit acceptance of the Chandlerian view of the large NFC [non-financial corporations] as an integrated, coherent combination of relatively illiquid real assets assembled to pursue long-term growth and innovation, to a "financial" conception in which the NFC is seen as a 'portfolio' of liquid subunits that home-office management must continually restructure to maximize the stock price at every point in time (Crotty, 2002, p. 17).

Another major condition on which the transformation of the pattern of organization and accumulation of the Brazilian industry is based is the exhaustion of the ISI standard, largely ongoing up to the 1980s. This exhaustion, in turn, derives both from the transition from the Chandlerian techno-economical paradigm to one based on microelectronics and from the crisis of developmentalism. As pointed out by Coutinho (1992), the consolidation of this new paradigm derived from the impacts caused by the technological revolution in microelectronics. According to the author, the increase in the importance of the electronic complex, especially with regard to its influence on other economic activities, is central to understanding the bases of this new paradigm. This is because electronics is a fundamental tool to enable transformations, be it organizational (revolution in labor processes, transformations in business structures), productive and technological (growing importance of the electronic complex and integrated and flexible automation) or competitive (reorganization of business strategies and new bases of competitiveness associated with the intensification of internationalization).

(8) According to the authors of the regulationist school, the consolidation of a new, said to be finance-led, regime of capitalist accumulation on a global scale would take place as a result of this restructuring. Boyer mentions (2000) that finance plays the central role, which was previously attributed to labor links in Fordism. For a detailed understanding of this regime see, among others, Aglietta and Orlean (1990), Aglietta (2004), and even Aglietta (1976). 
Considering the profound transformations of the techno-economic paradigm, the crisis of developmentalism, when associated with an international phenomenon of liberal reaction, entailed a vast set of measures that unfolded into the abrupt and intense commercial and financial opening. The crisis culminated in strong fluctuations in macroeconomic prices, characterized since then by the persistent appreciation of the real, high interest rates and low public investment (both in infrastructure and in the social dimension) (Carneiro, 2002).

In this scenario, the local industry has adopted a movement of defensive reaction, marked by the interruption of the characteristic dynamics of the ISI period, based on the expansion of investment directed to the diversification of the domestic productive capacity.

As a way of reacting to the broader constraints of this context, understood mainly by the developmentalist literature as one of regressive specialization (Coutinho, 1997), the thesis upheld here is that the defensive reaction of the Brazilian industry engendered transformations that gave rise to a new standard of organization and accumulation in effect in the first decade of the $21^{\text {st }}$ century. This pattern is based on the following tripod:

(i) reorganization of local productive units, adapting them to the new competitive constraints of global production networks and thus enabling, essentially, the integration of imports into these networks;

(ii) expansion of the internal market, fostered by income distribution, increases in the volume of wages, employment and credit; and

(iii) inclusion of the domestic production into the international market as a major provider of natural resource intensive.

In this tripod, while the consolidation of China as one of the main cyclical centers of the global economy enhanced accumulation strategies based on import-oriented integration into global production networks and in the connection to its voracious demand for commodities, the economic and social transformations that took place during Lula's presidency strengthened accumulation strategies targeted at the supply of wage-goods. According to Bielschowsky (2012), this movement is due to four factors:

i) the rapid increase in wage volume, rate of employment and increase in income from labor; ii) income transfers to the poor population, via social policies such as the impact of the increase in the minimum wage on pensions and the 'Bolsa Familia'; (iii) stability or decrease in the prices of popular industrial goods as a result of the appreciated exchange rate and the import of goods from China and Asia; iv) strong expansion of credit to consumption and the low-income population's access to it (Bielschowsky, 2012, p. 738, free translation).

In other words, based on the limitations imposed by the liberal reaction to the developmental crisis associated with the change in the global techno-economic paradigm, Brazilian industrial companies have adapted so their dynamism and accumulation is based on each of the three tripod bases cited above, in different levels according to sectoral specificities. 
As a result of these transformations, the emergence of this new pattern of organization and accumulation of the local industry gave rise to what we call here the Brazilian Disease. It is characterized by a scenario in which the industry exhibits structural reconfigurations towards regressive specialization and deindustrialization alongside the emergence of strategies that ensure the accumulation of industrial capital. This accumulation, in turn, is associated with the emergence of strategies that are increasingly unlinked to a strictly productive performance. In other words, the coexistence of a process of deindustrialization with the maintenance and expansion of the accumulation of local industrial capital can be seen in Brazil in the 2000s.

This denomination, in turn, is an allusion to the Dutch Disease, understood by numerous studies, such as those by Bresser-Pereira (2005; 2008, 2010), Bresser-Pereira and Marconi (2010), Oreiro and Feijó (2010) and Palma (2005), as one of the central causes of Brazilian deindustrialization. Synthetically, the Dutch Disease phenomenon explains the decreased role of industry in economic development as a result of the appreciation of local currencies due to thriving exports in the commodity sectors and the inflow of speculative capital encouraged mainly by the different levels of internal and external interest rates, increasing the rate of return and relative attractiveness of these sectors in relation to manufacturing activities. According to Bresser-Pereira (2008),

The Dutch disease is an obstacle on the demand side by rendering investments impossible even when companies dominate their technology (because) there will be a chronic lack of opportunity for profitable investments in the sectors producing marketable goods, whose main cause will be the trend towards the overvalued exchange rate that exists in developing countries (Bresser-Pereira, 2008, p. 1-2, free translation).

Different from this interpretation, we hold that more than the supposed reduction in the rate of return of the manufacturing sector, the low local productive dynamism in the 2000s is explained by a new pattern of organization and accumulation of the local industrial sector. As a result, the Brazilian industry was able to adapt and reconfigure its productive activities, gradually reducing the local content added to its production. This reduction, in turn, was accompanied by the growth of imports of final products, parts, pieces and components stemming from the import-oriented integration into global production chains. The emergence of a domestic industry with competitive dynamics and accumulation, completely different from that prevailing in the Asian countries that managed to engender a virtuous external insertion through the export of manufactured goods, was thus observed.

As a reflection of the Brazilian Disease, a trend in the productive dimension has been observed since the 1980s, one of a persistent reduction in the participation of the industry in GDP and in its contribution to growth (which stood at levels close to 35\% in the 1980s and systematically below $20 \%$ in the 2000s). Also, in addition to the low dynamism, it is worth stressing that about $50 \%$ of the growth in the rates of industrial value added (VA) between 
2000 and 2010 was explained by sectors intensive in natural resources. ${ }^{9}$ Thus, when analyzing the percentage distribution of the rate of industrial value added according to types of technology, we can verify that the Brazilian industry has concentrated its efforts in the segment that is intensive in natural resources, a phenomenon that was consolidated at the turn of the century and has been intensified even more deeply since the end of the 2000 s.

Simultaneously with this concentrated rate of industrial value added in sectors which are intensive in natural resources, there has been a decline in the representativeness of countless other sectors with high value added and a high capacity to irradiate productivity gains for other global production networks. Examples of this are as those typical of the techno-economic paradigm of electronics, the manufacturing sectors of means of production (machinery and equipment, chemical and pharmaceutical industries), in addition to labor-intensive sectors.

This concentration is accompanied by a widespread loss of global production networks (Morceiro, 2012), from leading sectors in the process of accumulation of the Chandlerian industrial paradigm - such as metal-mechanics, chemistry, and machinery and equipment - to the aircraft manufacturing sector. Measured by the relationship between the rate of industrial value added and the gross value of production, this loss of links is understood, by authors such as Nassif (2008), as one of the main indicators of the deindustrialization trend.

As a result of the evidence for deindustrialization and adherence to the Brazilian Disease scenario, an increase in the penetration coefficient of imports in parallel to a polarized performance of the sectoral balance sheet can be seen in the external dimension. While an improvement in the commercial balance of the group of sectors intensive in natural resources can be observed from the mid-2000s onward, there has been a substantial deterioration in the balance of the other groups of sectors, which has resulted in significant and increasing deficits since the end of the decade.

As a reflection of the diffusion of local production networks, accompanied by an increase in the penetration coefficient, there was a widespread fall in the intensity of capital per worker.

(9) These sectors were classified according to the taxonomy created by Pavitt (1984) and internalized by the OECD in several studies, such as OECD, 2005. The OECD (2005, p. 182) considers sectors based: on science (Pharmaceuticals; Office, accounting and computing machinery; Electrical machinery and apparatus; Instruments and appliances for measuring, checking, testing and control; Machinery and equipment for industrial automation; Aircraft and spacecraft; based on natural resources (Mining of coal; Extraction of petroleum, natural gas and related services; Extraction of metallic minerals; Extraction of nonmetallic minerals; Food and beverages; Tobacco products; Manufacture of leather and related products; Products of wood; Manufacture of paper and pulp; Manufacture of coke and refined petroleum products; Manufacture of alcohols; Metallurgy of non-ferrous metals; Manufacture of cement and other non-metallic mineral products); labor-intensive (Textiles; Clothing; Travel articles and other leather articles; Footwear; Manufacture of metal products (except machinery and equipment); Furniture and diverse industries); scale-intensive (Ceramic products for civil construction and other uses; Manufacture of products and articles of paper and paperboard; Editing, printing and reproduction of recorded media; Chemical products; Articles of rubber and plastic; Glass and products of glass; Basic metallurgy; Automotive vehicles; Equipment for railroad, shipping and other transport, except aircraft); and different (Machinery and equipment; Electric machinery, equipment and material; Electronic components and communication equipment; Medical equipment; Optical instruments, watches and clocks). Based on this definition, these sectors were aligned with the activities described by the National Classification of Economic Activities (CNAE), in which the data from the Annual Industrial Survey (PIA) from the Brazilian Institute of Geography and Statistics (IBGE) are disclosed. 
Figure 1

Growth rate of the ratio total asset/EP, according to sectors grouped by type of technology, 2000-2010

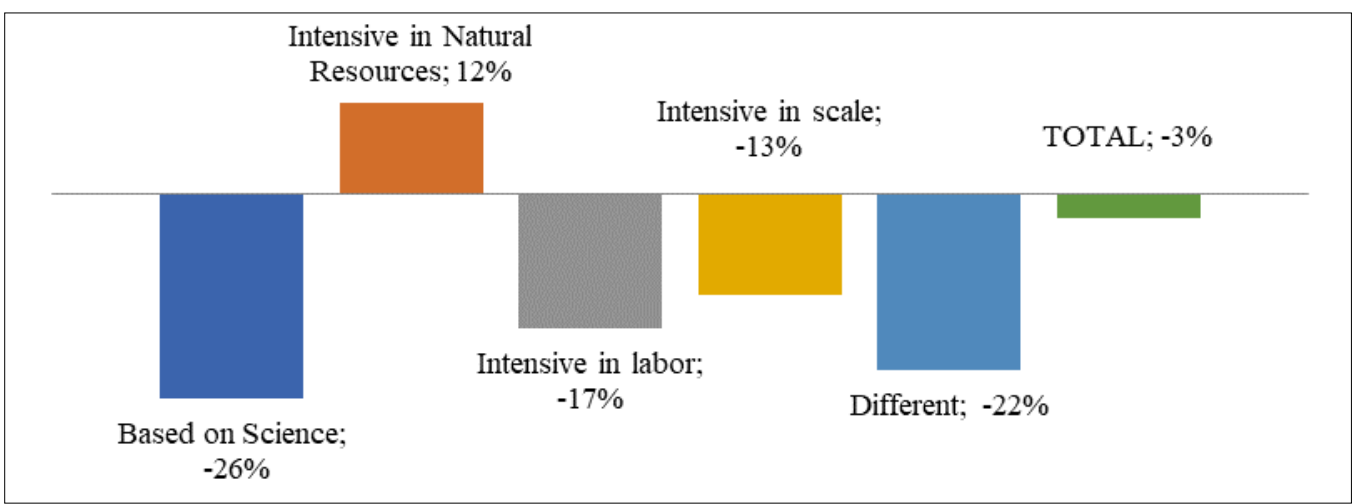

Source: Authors, based on PIA - IBGE (several years). Classification based on OECD (2005), from Pavitt (1984). Data deflated according to IPA -FGV. Companies with 30 ou more employees.

See methodological notes in footnote 10 .

Measured by the ratio between total assets and employed personnel (EP), the decrease in this indicator was more intense in science-based and different sectors (which also showed a significant reduction in the productive density and increase in the penetration coefficient). Once again, the exception to this phenomenon was the group of natural resource intensive sectors, which accounted for $86 \%$ of the growth of Brazilian industrial assets between 2000 and $2010^{10}$. Similarly to this phenomenon, according to Rocha (2015) while reiterating the conclusions of Kupfer and Laplane (2010), we can observe that "the combination of a high rate of return during the period before the crisis and the uncertainties in relation to exchange and interest

(10) The data used to analyze the behavior of the Brazilian industry in the aforementioned period originate mainly from the PIA - IBGE survey. The object of analysis concerns the group of companies with 30 or more employees and which are classified as belonging to the industry (extractive and manufacturing). It is worth stressing that the use of this database makes it possible to circumvent a common limitation of several studies that analyze the behavior of profitability of the Brazilian industry and which will be debated throughout this section, namely the focus of their analyses on publicly traded and the largest privately held corporations (Petrobrás, Eletrobrás and Vale) from data arrayed by sources such as Economática and annual reports published by large companies. Thus, the option for PIA-IBGE makes it possible to understand the dynamics of the organization and accumulation of all Brazilian industrial companies with 30 or more employees and not only of a restricted - albeit very significant - group of large companies. From these data, some indicators were built: (i) total profit - defined by the total revenue operation minus total costs and expenses; (ii) rate of return - defined as the division of total profit by total assets; (iii) profitability - division of total profit by total revenue; (iv) profit margin - division of total profit by total cost. It is worth noting that revenues derived from operations that are not strictly industrial - such as financial revenues, active monetary variations, positive results from equity holding and participation fees, among others - were also computed. Total costs and expenses, in turn, include spending with personnel (salaries and other contributions and charges), raw materials, stock, direct production costs and other costs (including depreciation). When analyzing the behavior of the assets according to the industrial sectors, from more than 600 observations, we identified eight which presented oscillations that materialized in values substantially different from those observed in the immediately previous and subsequent years, as well as in the remainder of the series. Our conjecture, even because of variations in the order of the magnitude presented, is that there may have been some kind of tabulation error in terms of the units (e.g., thousand, million, billion) used. These values implied extraordinary oscillations in outlying points in a series of indicators which presented highly stable behavior in the period between 2000 and 2010 as total assets divided by total revenue. Thus, as a precaution, we disregarded the impact of these observations on the analysis developed in this work. 
rates comprised a scenario in which investments in modernization grew at a pace far superior to investments in the expansion of productive capacity and research and development, consolidating typical behavior of the national industry in periods of high rates of return" (free translation).

However, although the evidence for deindustrialization presented in the preceding paragraphs suggests fragility in the local industry, contrary to what one would imagine from an extrapolation of studies which defend that there is an ongoing phenomenon analogous to the Dutch Disease in Brazil, we can see that profits in the industrial sector in real value nearly doubled between 2000 and 2010 for companies with 30 or more employees. Despite using a distinct methodology, based on the analysis of the balance sheet of large companies, Rocha (2015, p. 168-169, free translation) comes to a similar conclusion, showing that "from 2004 up to the crisis, most of the industrial sectors presented a considerable increase in asset rate of return, with the extractive industry presenting the highest levels". Similarly, Hiratuka and Rocha (2015) state that, between 2003 and 2010, the rate of return divided by the net worth of the 200 largest Brazilian economic groups was above 14\%, reaching its peak of $18 \%$ in 2007 . Additionally, the CEMEC-IBMEC (2015) analysis on the 2000s shows that the return on equity of the publicly traded and the largest privately held companies (Petrobrás, Eletrobrás and Vale), was $18.5 \%$ between 2005 and 2010, even with the effects of the 2008/2009 crisis (years in which the same indicator was $17.7 \%$ and $15 \%$, respectively).

Going beyond this exponential growth in profit volume, one can observe a displacement between the evolution of assets, revenue and profit in the industrial sphere (Figure 2).

Figure 2

Growth rates of total asset and total revenue minus total cost, according to sectors grouped by type of technology, 2000-2010

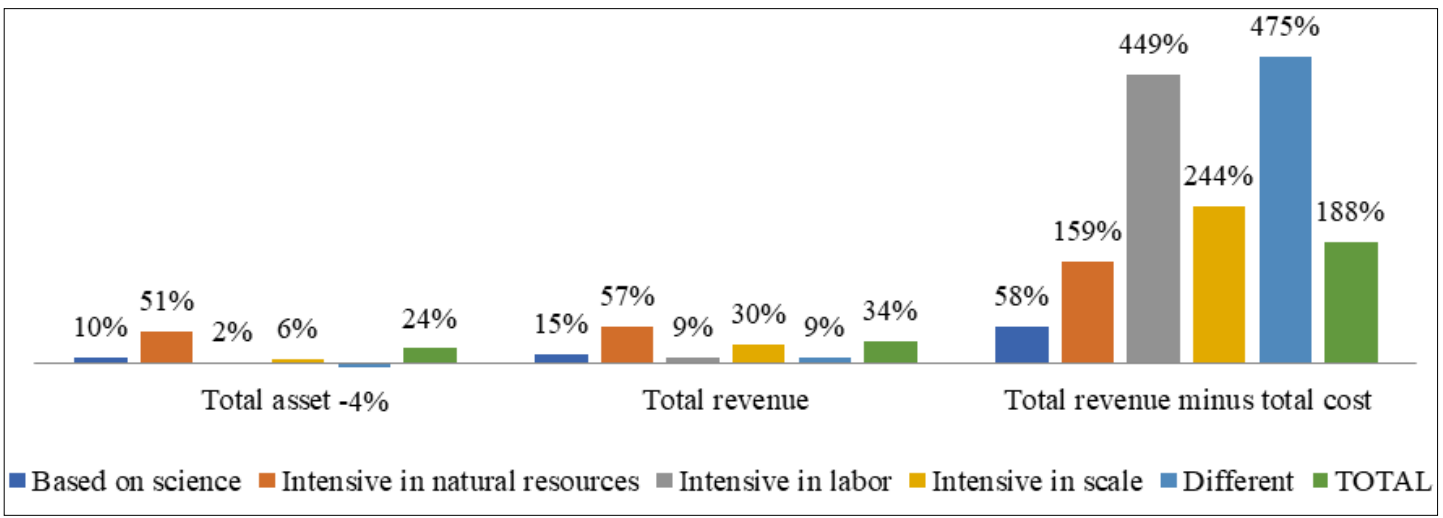

Source: Authors, based on PIA - IBGE (Several years). Classification based on OECD (2005), from Pavitt (1984). Data deflated according to IPA -FGV.

Companies with 30 ou more employees. See methodological notes in footnote 10.

This displacement is more intense in the sectors typical of the Third Industrial Revolution, the very ones that enabled the virtuous external integration of some Asian countries in global 
production networks. In summary, as a result of this phenomenon, the indicator's average expressed by the division of profit by revenue increased from $2 \%$ for the Brazilian industry in the 1996-2002 period to 9\% between 2003 and 2010. That is, despite the low investment dynamism, one can see that the Brazilian industry's new form of organization of capital accumulation freed it, albeit partially, from the chains of the productive activity in the first decade of the 21 st century.

Consistent with this movement, both the volume of profit and profitability indicators (profit/total revenue and profit/total cost) rate of return (profit/total asset) are directly proportional to the movements of currency appreciation throughout the whole decade analyzed. This movement is adherent to the Brazilian Disease scenario advocated in this article, due to the emergence of strategies that ensured the rate of return and profitability of the capital in the industrial sector even in a context of deindustrialization. It is also noteworthy that the improvement in the indicators occurs across all industrial sectors, including those of greater technological complexity. In turn, this fact contradicts (in the period under scrutiny) BresserPereira's (2013) perception that "in a scenario in which the effects of the Dutch disease are not neutralized, the profit rate of industrial companies in the marketable sectors will fall or even become negative (depending on the intensity of the disease) (...)" (Bresser-Pereira, 2013, p. 374 , free translation).

Since these strategies are based on the growing concentration of local industrial companies at the stages of commercialization, distribution, marketing and finance, the exchange appreciation contributed, by the gradual increase in the 'maquila' nature of the local manufacturing activity and by the use of external indebtedness as a source of funding, to increased industrial profitability and rate of return during a significant increase in the domestic consumer market in the 2000s (Figures 3 and 4).

Figure 3

Brazilian industry, selected indicators, 2000-2010 (\% and $2010 \mathrm{R} \$$ billion)

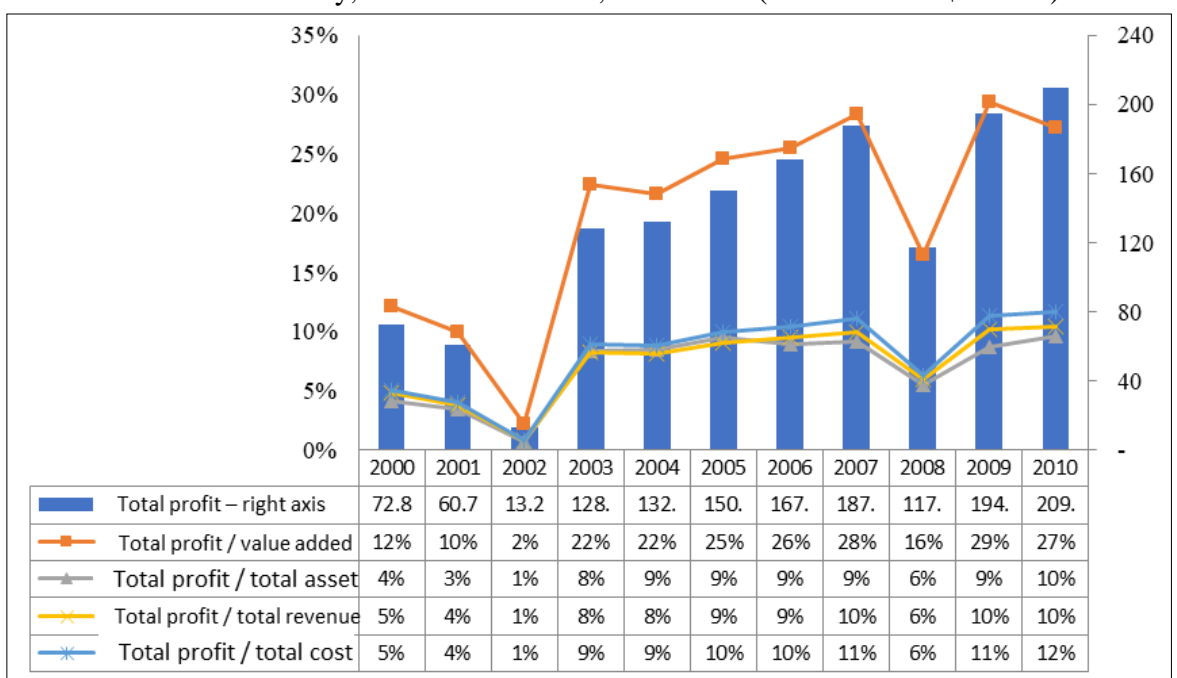

Source: Authors, based on PIA - IBGE (Several years). Data deflated according to IPA - FGV. Companies with 30 or more employees. 
Conversely, periods characterized by abrupt depreciation of the local currency are associated with a deterioration of industrial profitability and rate of return, be it due to increased costs of the financial services of business debts, a higher price of imported parts, pieces, components and final products, or even the fact that this depreciation is associated with moments of domestic and international economic and financial instabilities.

Figure 4

Monthly Exchange Rates (average), ratio between US\$ / R\$, 2000-2010

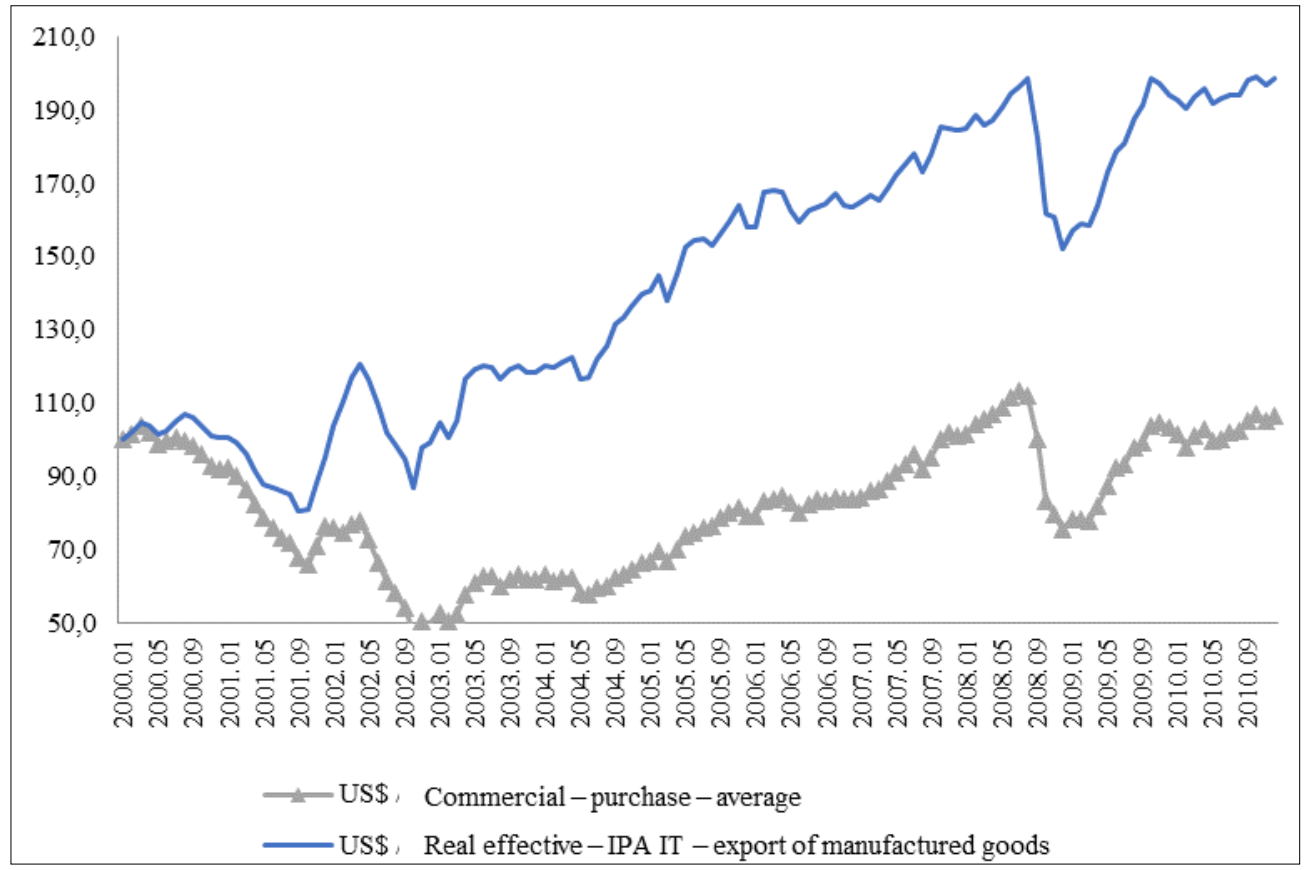

Source: Authors from BACEN - Bulletin (Several years).

It is precisely in this scenario of the Brazilian disease, where the dynamics of accumulation were disconnected, albeit partially, from a strictly productive performance, that one must attempt to understand the causes of the low dynamism of industrial investment throughout a decade-long growth of local consumption.

Complying with the thesis defended in this article, this low dynamism is in fact the symptom of a successful pattern of organization and accumulation, ongoing in the first decade of the 21 st century. In turn, according to mainstream interpretations, the low dynamism of investment is explained by two main lines of argument.

The first of them contends that increasing the real wage above productivity reduced the industry's profitability and rate of return. This fact restricted the sector's investment capacity and, thus, compromised its long-term growth potential. As highlighted by Pastore et al. (2013),

The increase in wages, combined with stagnation followed by declining labor productivity in the industry, led to a rise in the unit cost of work. This was enough to annul the stimulus 
from the decrease in the real interest rate and to increase the product's negative hiatus and reduce the utilization of the installed capacity (Pastore et al., 2013, p. 120, free translation).

Therefore, one of their prerequisites of increased competitiveness of the local industry and the subsequent investment revival would be the limitation of the real wage growth rate to levels below the rate of the expansion of productivity.

However, despite what this line of argument asserts, neither the rate of return nor profitability of the local industry fell in the period from 2000 to 2010 . When observing the behavior of wages in relation to costs and industrial profit, it is also not possible to affirm that the growth of real wages by itself reduced the investment potential of the national industry. This is because, according to PIA/IBGE, for companies with 30 or more employees, the participation of expenses on personnel (which include other obligations beyond wages) in industrial costs in 2010 was at exactly the same level as in $2000-13.9 \%$ (Figure 5).

In addition, refuting what some prominent interpretations in the current economic debate suggest, from 2000 to 2010, there was no increase in the participation of expenditure on personnel in relation to the profit of Brazilian industrial companies. Rather, expenses on employees accounted for about $120 \%$ of the profits in 2010 , while the values were substantially higher in 2000 and $2001,273 \%$ and $318 \%$, respectively.

Figure 5

Indicators of expenditure with personnelrelated to total cost, total revenue and volume of profit in the Brazilian manufacturing industry, 2000-2010

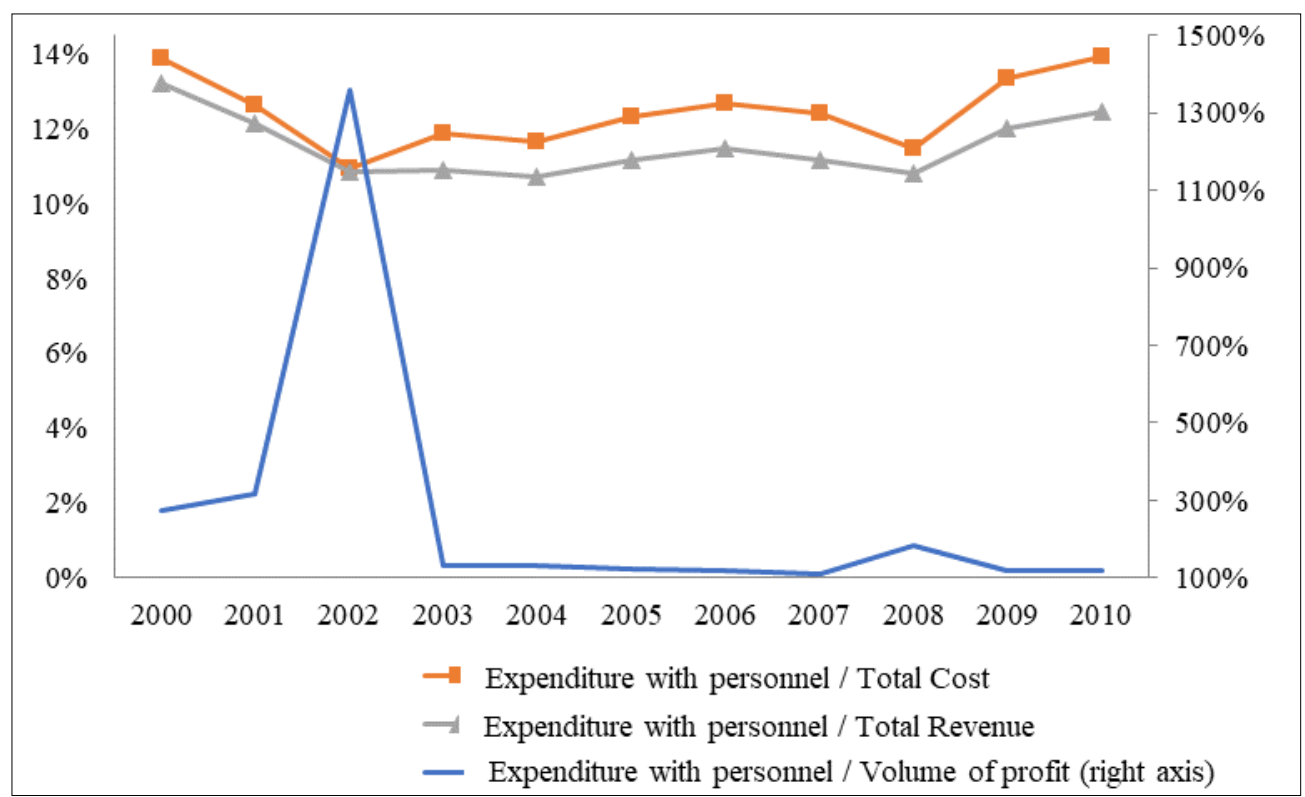

Source: Authors, from PIA - IBGE (Several years). Data deflated according to IPA - FGV. Companies with 30 or more employees. 
The second mainstream interpretation regarding the causes of low dynamism in Brazilian investment suggests that it would be an indirect reflection of the State fiscal crisis. In this context, by incurring increasing nominal fiscal deficits, the State would discourage restoring investments through increased uncertainty associated with the alleged reduction in its solvency capacity and with crowding out. The reason for this is that, in an unstable context, the horizon of predictability decreases and expectations about future profitability are negatively affected. Hence, only fiscal contraction perceived as sufficiently robust and believable by economic agents could reverse the scenario, lower expectations and thus release the local entrepreneurial spirit in order to enable the revival of industrial investments.

In addition to the capitalist mechanisms of automatic transmission between expectations and investment decisions being questionable (Galbraith, 2006; Serrano; Braga, 2006), the fiscal contraction associated with stagnation contributes negatively to the support of that which was one of the pillars of the tripod of accumulation of industrial capital in the 20002010 period: the increase in the domestic market, fostered by the distribution of income, and increase in the volume of wages, employment and credit. Also, as has been discussed throughout this work, given the fact that the accumulation of capital in Brazilian industry allowed it to release itself, even if only partially, from the chains of productive activity, a possible improvement in economic expectations would not necessarily imply an increase in productive investment.

However, it is not overstating to reiterate that the characteristics of this process relate fundamentally to the first decade of the 21 st century. As previously sustained, the combination of deindustrialization and increased accumulation capacity was only feasible due to the existence of elements that materialize in the tripod: (i) reorganization of local production units, with an increase in the import-oriented integration into global production networks; (ii) strength of the domestic market; and (iii) connection of the domestic productive capacity to the international market as a major provider of products which are intensive in natural resources.

Overall, this article recognizes that import-oriented integration into global networks is structural in character, as it emerges as a result of the combination between the exhaustion of the Brazilian industrialization model by import substitution alongside the reorganization of corporations and of global production systems in a context of "industrial Chinalization" (Sarti; Hiratuka, 2017).

The other factors, in turn, present a cyclical character. Therefore, given the strong reversal in the growth of the domestic market in the second decade of the 21 st century, one could expect that the Brazilian industry would have difficulties maintaining the accumulation dynamics of the previous period in the face of a fall in demand. This observation is also fitting when analyzing the impacts of the decrease in the commodity price boom on the dynamics of accumulation of local companies exporting natural resource intensive products.

In this context, due to the reconfiguration of the tripod elements that enable deindustrialization movements to coexist alongside an increase in the accumulation of the 
Brazilian industry, evidence points to the collapse of this process in the second decade of this century. Once again, we emphasize that the curse of the phenomenon termed here as the Brazilian Disease refers to the behavior of the Brazilian industry from 2000 to 2010 and is derived from specific conditions that allowed a form of organization and accumulation advantageous to the capital allocated in the industrial sphere, but incompatible with a development strategy characterized by structural changes towards highly productive domestic manufacturing activities.

Since the process of import-oriented integration of the local productive capacity into global production networks presents components of a structural nature, the reversal of the cyclical movement of appreciation of the local currency from the 2010s onwards would tend to contribute negatively to the accumulation of capital allocated in the industrial sphere. This negative contribution would result from the increase in costs of imported inputs and products and would be enhanced by the increase in the volumes of local currency which are necessary for the rollover and amortization of debts contracted by local companies in the international market. The potential dimension of this impact can be perceived when one verifies that, in 2014 , for example, the international market accounted for $54.3 \%$ of the total funding of publicly traded companies (with the exception of Vale and Petrobrás) of the manufacturing industry (CEMEC-IBMEC, 2014). According to Gomes, Novais and Rocha (2016, p. 16, free translation), "this means that the level of the exchange rate does not have a unique effect in relation to stimuli for the industry, and that, in equating growth, the weight of financial expenses may play a fundamental role in the short term (..)".

In addition, the deceleration of the domestic consumer market and its subsequent retraction, as well as the exhaustion of the international commodity price boom, would also tend to negatively affect the dynamics of the accumulation of industrial sectors connected to the domestic market and the export of natural resources.

Thus, one would expect a fall in the profitability and the rate-of-return indicators of industrial companies from the 2010s onwards. Enhanced by the negative impacts of local currency depreciation on the evolution of the amount (as well as the rolling and amortization) of debt in US dollars, these impacts would contribute to the deterioration of the capacity of industrial accumulation in the period.

As stated in CEMEC-IBMEC $(2014,2015)$, this decline in profitability is understood as one of the main causes of the low dynamism of Brazilian investment after 2010. According to the 2014 report (p. 2, free translation):

everything points to the decline in the rate of return on the capital invested to levels below the average debt cost of these companies, since 2012, as one of the most relevant factors to explain this performance. Especially in the industrial sector, the problem appears in the form of margin reduction, which results from the difficulty in transferring the increase in costs to sales prices, particularly the unit labor cost that has risen far above the price in reais of imported products, which was in turn reduced by the appreciation of the real. 
As an example, in the same year, the return on equity of the publicly traded and the largest privately held companies (Petrobrás, Eletrobrás and Vale), reached 7.2\%, after having always been kept at levels above 20\% between 2005 and 2007, and 17\% in 2010. Although the report presents these specific indicators of return on capital in an aggregate manner, it emphasizes that "the sector that has the highest profit reduction is industry" (p. 11, free translation).

The underlying thesis is that such a deterioration in the accumulation capacity is the main cause for the drop in the domestic economy's productive investment. Ultimately, this reduction in investment would explain the inability to engender a structural change process associated with increased productivity and domestic income growth.

However, although the decline in the rate-of-return indicators shows a lower accumulation potential after 2010, the organization of the Brazilian productive system engendered since the beginning of the 2000s introduces elements that question the validity of the idea expressed in the preceding paragraph. This is because, given this organization, the increase in accumulation is not necessarily linked to the increase in productive investment. Rather, as we demonstrated when we analyzed the 2000-2010 period, the characteristics of the international insertion pattern of the Brazilian productive capacity allow, in a scenario of intensifying internal and external demand, for accumulation to dispense, albeit partially, the execution of a substantial part of the production process nationally and, consequently, the need for substantial productive investments.

Thus, this article maintains that the resumption of the central role of industry in the Brazilian development strategy, in a context of global competition and consolidation of China as the new "Workshop of the World", should not be based on measures such as the decline in the growth rate of the real wage and the potential positive impacts of a supposedly expansionist fiscal contraction in industrial investment, as suggested by the liberal approach.

More broadly, such measures should consider the changes in the pattern of organization and accumulation of the local industry forged in the first decade of the 21st century. They should also be based on the understanding that an important part of the shortcomings of the Brazilian industry is structurally based on elements such as the low level of institutionalization of operational and innovative routines, the low intensity of capital per worker (which decreased in most sectors from 2000 to 2010, due to the increasing 'maquila' nature of the local industry) and mainly the low participation in the domestic productive structure of highly productive sectors, typical of the Third Industrial Revolution paradigm.

\section{Final remarks}

The analysis of the Brazilian industry in the last thirty years highlights the retraction of high-technology sectors at the expense of a constant increase in sectors of low differentiation, such as those intensive in natural resources. This movement gained prominence 
after the liberalization measures of the 1990s, which inserted the Brazilian industry in a scenario of international competition and consolidation of network firms.

In this context, the subsequent reductions in the participation of strategic industrial sectors in economic development have allowed many authors to identify a deindustrialization movement underway in Brazil. An intense debate about this process resulted in several studies, and it was possible to present a new taxonomy of the literature in this paper. We suggested that, instead of the traditional dichotomy that separates stances on this subject, the theses about the changes in the Brazilian productive structure are grouped into four approaches (socialdevelopmentalist, neo-developmentalist, liberal, and São Paulo business elite) based on criteria such as theoretical foundations, institutional linkage, the importance of the industry for development, determinants of the processes of change in the productive structure and institutional infrastructure, as well as prescriptive guidelines of industrial policies suitable for industrial development.

In addition, in a scenario of crisis of developmentalism and the end of the Chandlerian techno-economical paradigm, the emergence of a new pattern of organization and accumulation of the local industry in the 2000s can be observed, a pattern termed here the Brazilian Disease. This pattern is based on strategies of industrial organization and accumulation based on the reorganization of local productive units in the face of the competitive constraints of global production networks, the growth in domestic demand and the attachment of the domestic productive capacity to the international market as a major provider of natural resource intensive products.

In the context of the Brazilian Disease, there was an emergence of competitive strategies and accumulation that enabled the coexistence of a process of deindustrialization alongside the maintenance and even the expansion of the accumulation of capital invested in the local industry. Thus, we concluded that, in addition to the effects of the alleged deindustrialization, the changes in the pattern of organization and accumulation of the industry in the first decade of the 21st century substantially reduced its capacity as a catalyst of a growth process associated with diversification and structural transformations based on the increase and intersectoral dissemination of productivity.

It should be noted, however, that the interpretation suggested in this work is restricted to the 2000-2010 period, for reasons previously mentioned. Thus, despite the empirical evidence for the continuation of the deindustrialization process after 2010, we do not claim that the extrapolation of the thesis presented here is enough to understand the accumulation dynamics of the Brazilian industry in the 2010s. On the contrary, one can observe that the coexistence of deindustrialization and growth of accumulation (a trait of the Brazilian Disease) was exhausted in the cycle of deceleration and growth reversal that took place between 2011 and 2016. This is because the recession of recent years has caused a rapid and drastic reduction in the dynamism and profit rate of the domestic industry, which is explained by the reorganization of the tripod and its organizational model that was sustained from 2000 to 2010. 
Beyond deindustrialization: changes in the pattern of industry organization and accumulation in a scenario of the 'Brazilian Disease'

\section{References}

AGLIETTA, Michel. Régulation et crises du capitalisme: l'expérience des États-Unis. Paris: Calmann-Lévy, 1976.

AGLIETTA, Michel. Macroeconomia financeira: mercado financeiro, crescimento e ciclos. Paris: Edições Loyola, 2004. v. 1.

AGLIETTA, Michel; ORLÉAN, André. A violência da moeda. São Paulo. Editora Brasiliense, 1990. 430p.

ALMEIDA, Julio Sergio Gomes; NOVAIS, Luis Fernando e ROCHA, Marco Antonio. A fragilização financeira das empresas não financeiras no Brasil pós-crise. Campinas: Unicamp. IE, 2016. (Texto para Discussão, n. 281).

BACHA, Edmar; DE BOLLE, Monica Baumgarten. O futuro da indústria no Brasil: desindustrialização em debate. Rio de Janeiro: Civilização Brasileira, 2013.

BENAVENTE, José Miguel; CRESPI, Gustavo; KATZ, Jorge; STUMPO, Giovanni. Nuevos problemas y oportunidades en el desarrollo industrial de América Latina. Cuadernos de Economía, v. 15, n. 25, p. 33-67, 2010.

BELlUZZO, Luiz Gonzaga; ALMEIDA, Júlio Sérgio. Depois da queda: a economia brasileira da crise da dívida aos impasses do Real. Rio de Janeiro: Civilização Brasileira, 2002.

BIELSCHOWSKY, Ricardo. Pensamento econômico brasileiro: o ciclo ideológico do desenvolvimentismo. Rio de Janeiro: IPEA/INPES, 1988.

BIELCHOWSKY, Ricardo. Estratégia de desenvolvimento e as três frentes de expansão no Brasil: um desenho conceitual. Economia e Sociedade, Campinas, v. 21, p. 729-747, 2012.

BONNELLI, Regis; PESSÔA, Samuel de Abreu. Desindustrialização no Brasil: um resumo da evidência. Faculdade Getúlio Vargas, 2010. (Texto para Discussão, n. 7).

BOYER, Robert. Is finance-led growth regime a viable alternative to Fordism? A preliminary analysis. Economy \& Society, v. 29, p. 111-145, Feb. 2000.

BRESSER-PEREIRA, Luiz Carlos. Doença holandesa e sua neutralização: uma abordagem ricardiana. Doença holandesa e a indústria. Rio de Janeiro: Editora da Fundação Getúlio Vargas, 2008.

BRESSER-PEREIRA, Luiz Carlos. Brasil vive desindustrialização. Folha de S. Paulo, 2010.

BRESSER-PEREIRA, Luiz Carlos. The value of the exchange rate and the Dutch disease. Revista de Economia Política, v. 33, n. 3 (132), p. 371-387, jul./set. 2013.

BRESSER-PEREIRA, Luiz Carlos; MARCONI, N. Existe doença holandesa no Brasil? In: BRESSER-PEREIRA, L. C. (Org.). Doença holandesa e indústria (coletânea). Rio de Janeiro: Editora FGV, 2010. 
CANO, Wilson. A desindustrialização no Brasil. Campinas Unicamp. IE, 2012. (Texto para Discussão, n. 200).

CARNEIRO, Ricardo. Desenvolvimento em crise: a economia brasileira no último quarto do século XX. São Paulo: Editora Unesp, IE/Unicamp, 2002.

CEMEC-IBMEC. Análise da composição do exigível financeiro das companhias abertas e fechadas não financeiras. São Paulo: IBMEC, 2014.

CEMEC-IBMEC. Nota CEMEC - Fatores da queda do investimento 2010-2014. São Paulo IBMEC, 2015.

CIMOLI, Mario et al. Heterogeneidad estructural, asimetrías tecnológicas y crecimiento en América Latina. 2005.

COUTINHO, Luciano Galvão. A terceira revolução industrial e tecnológica. Economia e Sociedade, Campinas, n. 1, 1992.

COUTINHO, L. C. A especialização regressiva: um balanço do desempenho industrial pósestabilização. In: VELLOSO, J. P. R. (Org.). Brasil: desafios de um país em transformação. Rio de Janeiro: José Olympio Editora, 1997.

CROTTY, J. The effects of increased product market competition and changes in financial markets on the performance of Nonfinancial Corporations in the neoliberal era. 2002. (PERI Working Paper, n. 44).

FEIJÓ, Carmem; CARVALHO, Paulo. Desindustrialização e os dilemas do crescimento econômico recente. Estudos IEDI, São Paulo, 2007.

FIESP. O processo de desindustrialização. São Paulo: Departamento de Pesquisas e Estudos Econômicos, 2011.

FIESP. Seminário Reindustrialização do Brasil: chave para um projeto nacional de desenvolvimento. São Paulo, SP, 2013.

GALBRAITH, James. The fiscal facts: public and private debts and the future of the American economy. Levy Institute, 2006. (Levy Institute Policy, Note 2).

HIRSCHMAN, Albert. The strategy of economic development. New Haven: Yale University Press, 1958. v. 10.

HIRATUKA, Célio; ROCHA, Marco Antonio. Grandes grupos no Brasil: estratégias e desempenho nos anos 2000. Brasília: Ipea, 2015. (Texto de Discussão).

HIRATUKA, Célio; SARTI, Fernando. Transformações na estrutura produtiva global, desindustrialização e desenvolvimento industrial no Brasil: uma contribuição ao debate. Campinas: Unicamp. IE. 2015. (Texto para Discussão, n. 290). 
Beyond deindustrialization: changes in the pattern of industry organization and accumulation in a scenario of the 'Brazilian Disease'

KALDOR, Nicholas. Causes of the slow rate of economic growth of the United Kingdom. Cambridge: Cambridge University Press. 1966

KALDOR, Nicholas. Problems of Industrialization in Underdeveloped Countries. Ithaca: Cornell University Press. 1967

KUPFER, David; LAPLANE, Mariano. Perspectivas do investimento no Brasil: síntese final. Campinas: Unicamp; Rio de Janeiro: UFRJ, 2010.

KUZNETS, Simon; MURPHY, John Thomas. Modern economic growth: rate, structure, and spread. New Haven: Yale University Press, 1966.

NASSIF, André. Há evidências de desindustrialização no Brasil? Revista de Economia Política, v. 28, n. 1, p. 72-96, 2008.

MORCEIRO, Paulo. Desindustrialização na economia brasileira no período 2000-2011: abordagens e indicadores. Dissertação (Mestrado em Economia)-Universidade Estadual Paulista, Faculdade de Ciências e Letras, Campus de Araraquara, Araraquara, 2012.

ORGANIZATION FOR ECONOMIC COOPERATION AND DEVELOPMENT. Structural adjustment and economic performance. Paris: Organization for Economic Cooperation and Development, 1987. 371p.

ORGANIZATION FOR ECONOMIC COOPERATION AND DEVELOPMENT. OECD science, technology and industry scoreboard 2005. Paris: Organization for Economic Cooperation and Development, 2005. 210p.

OREIRO, José Luís; FEIJÓ, Carmem. Desindustrialização: conceituação, causas, efeitos e o caso brasileiro. Revista de Economia Política, v. 30, n. 2 (118), p. 219-232, 2010.

PALMA, José Gabriel. Quatro fontes de desindustrialização e um novo conceito de doença holandesa. In: CONFERÊNCIA DE INDUSTRIALIZAÇÃO, DESINDUSTRIALIZAÇÃO E DESENVOLVIMENTO. Federação das Indústrias do Estado de São Paulo, 2005.

PASTORE, Affonso Celso; GAZZANO, Marcelo; PINOTTI, Maria Cristina. Por que a produção industrial não cresce desde 2010? In: O FUTURO da indústria no Brasil: desindustrialização em debate. Rio de Janeiro: Civilização Brasileira, 2013.

PAVITT, K. Sectoral patterns of technical change: towards a taxonomy and a theory. Research Policy, n. 13, p. 343-373, 1984.

PREBISCH, Raúl et. al. O desenvolvimento econômico da América Latina e seus principais problemas. Revista Brasileira de Economia, v. 3, n. 3, p. 47-111, 1949.

ROCHA, Marco Antônio. Transformações produtivas e patrimoniais no Brasil pós-crise. In: DIMENSÕES estratégicas do desenvolvimento brasileiro. Brasília: CGEE, 2015. v. 4.

RODRIK, Dani. One economics, many recipes: globalization, institutions, and economic growth. New Jersey: Princeton University Press, 2007. 
ROWTHORN, Robert; RAMASWANY, Ramana. Growth, trade and deindustrialization. IMF Staff Papers, v. 46, n. 1, 1999.

SARTI, Fernando; HIRATUKA, Célio. Desenvolvimento industrial no Brasil: oportunidades e desafios futuros. Campinas: Unicamp. IE, 2011. (Texto para Discussão, n. 187).

SARTI, Fernando; HIRATUKA, Célio. Desempenho recente da indústria brasileira no contexto de mudanças estruturais domésticas e globais. Campinas: Unicamp. IE, 2017. (Texto para Discussão, n. 290).

SERRANO, Franklin; BRAGA, Julia. O mito da contração fiscal expansionista nos EUA durante o governo. Economia e Sociedade, Campinas, v. 15, n. 2 (27), p. 213-239, ago. 2006.

THIRLWALL, Anthony Philip. A plain man's guide to Kaldor's growth laws. Journal of Post Keynesian Economics, v. 5, n. 3, p. 345-358, 1983. 